\title{
輻射熱負荷による体表面温度の変動
}

\section{Influence of Radiant Heat on Skin Temperature}

\author{
慶応義熟大学医学部衞生学・公衆衞生学教室 \\ 倉田正一・新井昌平・豊田和雄 \\ 東京都橴谷保健所 \\ 石原弘 純 \\ Masakazu Kurata, Shôhei Arai, Kazuo Toyoda \\ Department of Preventive Medicine and Public Health, School of Medicine, Keio University \\ Hirozumi Ishihara \\ Shibuya Health Center, Tokyo
}

住宅に扮沙々冬季採暖法としては現在輻射暖房が相当 な役割を演じている。輻射暖房といつても，乙こでは部 屋の壁や天井, 床自身を輻射体とする暖房方法ではなく て，ストーブ類による採暖法を意味しているのである が, との場合には，われわれの受计る輻射熱は身体のあ る1方向からのみ, 多くは前面からのみのととが多い。

A. Burton ${ }^{1)}$ によれば, F. Goldby らはオーストラリア に住む土民の採暖風習について記載していて, 彼らは凍 るょうな寒夜に真裸で火の側汇横臥就寝するという。も しこのょうな状熊が可能であるとすれば, 土民の寒冷馿 化はあるにしても, 裸体横臥時前面から受ける熱仙よつ て一体どんな熱関係を生ずるのであるらか。

著者らはさきに, 着衣状態で軽い作業をしている被検 者の前面から輻射熱を加えた場合起る身体熱収支の変動 の様子を観察したのであるが2)，その際，直接輻射熱汇 曝されない皮膚面, 特化躯幹部背面では, 室温安 $20^{\circ} \mathrm{C}$ 付 近保つと, 作業中皮膚温下降定示し, 室温が上昇して $30^{\circ} \mathrm{C}$ 越すようになつてはじめて該部皮膚温は下降から 上昇に転ずるのを認めたのである。とのととは, オース トラリア土民の風習と考元合わ方々と, 受熱面と放熱面 との間に何か微妙な協調が存在するととが暗示されてい るようであある。あるいは李た，輻射熱化よつて特殊な 血管反射でも起るのであろらか。著者らはことで, 前面 加輻射熱を受けたときの裸体横卧時の全身つ皮膚温分 布から本問題を検討してみをのである。

\section{1）実験方法}

輻射熱源としては, $3 \mathrm{KW}$ ニクロム線 3 本の背部に,
反射銅輝面 $120 \times 60 \mathrm{~cm}$ を置いて, 裸体横臥位つ被検者 の前面 $75 \mathrm{~cm}$ または $100 \mathrm{~cm}$ に設置しだ。

被検者は 6 名（21 23 瓷男子 5 名, 59 筬男子 1 名) で,まず裸体後体重を測定し，ついで横臥せしめて皮膚 温測定用熱電対を全身借貼布する。貼布部位は, 頭部 (後頭極), 顔頝部(前額中央), 胸部 (肩胛棘), 腹部 (剣状 突起, 測腹), 腰大腿部 (単蹊部, 大腿前, 後面), 上膊 (三角筋中央), 前膊 (内. 背面), 手部 (手掌, 手背), 下 腿部 (前. 後面), 足部 (足背) 合計 16 力所を主とした。 とれらとともに直腸温も熱電対で測定する。その後およ 兰30分安静保保ちながら皮膚温索測定する。との間, 環 境温度条件 (気温, 気湿, 気流, 輻射熱), ついで血圧, 脈博を測定し，発汗状態学観察するため Minor 法によ る沃度溉粉の塗抹を扣こなつてから, 輻射熱を負荷しは じめる。負荷は 1 時間とし, この間連続して皮膚温, 直 腸温を測定し, 終了直前再び血圧, 脈博を測定して負荷 を終る。再び体重を計量して, さきの測定値との差から 腎外水分排泄量算定した。

\section{2）成績ならびに考按}

実験中の空気温度条件は, 第 1 表仁示すd 万に, 気温 15 16ㅇ ¿中心としていが, 実験室の都合で, 実験中 数度にも及び気温上昇定きたした例がある。しかし多く は $0.5^{\circ} \mathrm{C}$ 内外の上昇化止めることができ心。いず㣗にし てもとの温度上昇は考慮に入れねばならない。

褀卧位被検者の前面办引輻射熱筀与えると，受熱皮虛 表面温度は当然直ちに急上昇しはじめ, 特に単蹊部は著

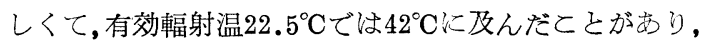


第 1 表 実験 温度条件

\begin{tabular}{|c|c|c|c|c|c|c|c|}
\hline 氏名 & 年齢 & 照射部位 & $\begin{array}{l}\text { 距離 } \\
\mathrm{cm}\end{array}$ & 乾球温度 ${ }^{\circ} \mathrm{C}$ & 比湿\% & 気流 $\mathrm{m} / \mathrm{sec}$ & $\begin{array}{l}\text { 有効輻射 } \\
\text { 温度 }\end{array}$ \\
\hline A & 21歳 & \multirow{7}{*}{ 前 } & 100 & $14.0 \sim 14.6$ & $46 \sim 39$ & $\sim 0.1$ & 12.0 \\
\hline B & 22歳 & & 100 & $13.7 \sim 14.3$ & $37 \sim 36$ & $\sim 0.3$ & 19.2 \\
\hline C & 23歳 & & 100 & $12.0 \sim 12.7$ & $34 \sim 35$ & $\sim 0.2$ & 17.0 \\
\hline D & 59歳 & & 75 & $17.3 \sim 17.7$ & $43 \sim 40$ & $\sim 0.4$ & 26.8 \\
\hline $\mathbf{E}$ & 23歳 & & 75 & $12.8 \sim 13.5$ & $36 \sim 32$ & $\sim 0.1$ & 19.0 \\
\hline B & 22歳 & & 75 & $14.8 \sim 15.3$ & $39 \sim 42$ & $\sim 0.1$ & 23.5 \\
\hline $\mathrm{E}$ & 23歳 & & 75 & $18.0 \sim 18.4$ & $43 \sim 50$ & $\sim 0.2$ & 18.0 \\
\hline D & 59歳 & \multirow[t]{4}{*}{ 面 } & 75 & $15.5 \sim 16.1$ & $41 \sim 39$ & $\sim 0.1$ & 20.0 \\
\hline F & 22歳 & & 75 & $16.8 \sim 17.3$ & $38 \sim 40$ & $0.1 \sim 0.2$ & 22.5 \\
\hline F & 22歳 & & 75 & $11.5 \sim 18.5$ & $45 \sim 38$ & $\sim 0.6$ & 23.0 \\
\hline $\mathrm{E}$ & 23歳 & & 75 & $18.0 \sim 17.0$ & $39 \sim 39$ & $0.3 \sim 0.4$ & 19.2 \\
\hline B & 22歳 & \multirow{3}{*}{ 額 } & 75 & $14.5 \sim 15.1$ & $34 \sim 33$ & $0.1 \sim 0.2$ & 22.0 \\
\hline $\mathrm{E}$ & 23歳 & & 75 & $16.3 \sim 16.8$ & $33 \sim 35$ & $\sim 0.2$ & 21.1 \\
\hline $\mathrm{E}$ & 23歳 & & 75 & $17.0 \sim 17.8$ & $33 \sim 39$ & $0.5 \sim 0.7$ & 13.1 \\
\hline B & 22歳 & 胸, 腹の前面 & 75 & $16.5 \sim 18.8$ & $49 \sim 38$ & $\sim 0.2$ & 20.3 \\
\hline
\end{tabular}

剣状突起部，大腿前面部皮膚面の上昇も著明である。な お，熱電対自身が輻射熱を 受けるが，とれによる測定 誤差は無視できる经ど小さかつた。とれ反して，輻射 熱を直接受けない三角筋部, 肩胛棘部, 大腿後面, 下腿 後面などの皮膚温は，気温により程度の差はあつても， 一様に輻射熱負荷前からひき続いて低下を続け，殊に比 較的低気温時には，物理的冷却を思わせるまうな下降を 示す。第 1 図は, 気温 $18^{\circ} \mathrm{C}$, 球温度 $36^{\circ} \mathrm{C}$ のときの例で ある。

第 1 図 皮润温分布（被検者 $\mathrm{E}$ ) 乾球温度 $18.0^{\circ} \mathrm{C}$ 有効輻射温 $18.0^{\circ} \mathrm{C}$

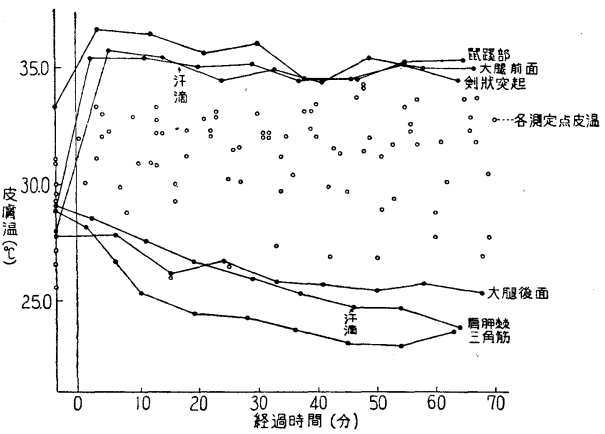

注目すべきは，1時間の観察期間中これら背面に招い て，ついに反射的な皮膚温上昇がみられなかつたととで ある。図中に示すよらに，直接輻射熱を受ける皮膚面， 特に胸部皮虐面では, 右半身(左半身を下にしている) 亿
受熱後 8 18分まず小汗滴が認められはじめ, 背面でも 少し遅れて同じく右半身に21 45分小汗滴が認められは じめたのである。すなわち，汗滴は，左半身よりも右半 身すなわち床に接している反対側の半身に高木 ${ }^{32}$ のいう 半側性発汗としてまず認められたのである。そとで，と の背部皮膚温下降注小汗滴による奪温のためではないか という疑も起るが, Minor 法で汗滴を認める前後を比較 してみても，特に発汗の影響を思わせる傾向はみられな いから，やはり主役を演じているのは物理的な冷却と考

\section{第 2 図 背部皮真温}

乾球温度 $26.0^{\circ} \mathrm{C}$ 有效輻射温 $18.0^{\circ} \mathrm{C}$

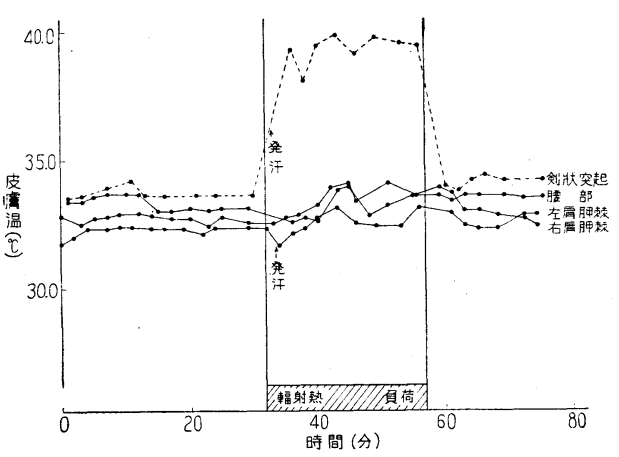

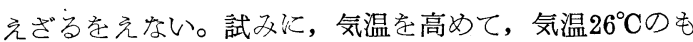
とで有効輻射温 $18.0^{\circ} \mathrm{C}$ 負荷してみても, 第 2 図にみる ょうに, 背面 (左右両肩胛棘部, 腰部) 皮膚温は低下は しないが，認むべき上昇はみられないのである。また 
M. Bader 弓4) は, 着衣椅坐位の被検者を気温 $15^{\circ} \mathrm{C}$ に掞 いて顔面を輻射熱加温してところ，80分後に手の皮膚温 は約 $10^{\circ} \mathrm{C}$ 上昇するが，他部位に認むべき上昇はなく，足 趾皮膚温淿被検者により多少の上景は西つ〔も, 背面皮 膚温は上昇しないのをみているのである。しかも, 気温 $23.5^{\circ} \mathrm{C}$ においても, 背面皮膚温上昇は起らなかったとい ら。著者らの前記裸体横臥位の被検者に, 気温 $16^{\circ} \mathrm{C} の も$ とで, 顔面の及を照射したときの成績は第 3 図に示すよ らであるが，Bader らの成績にみるような手の反射的皮

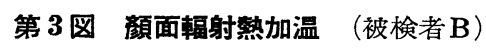
乾球温度 $14.5^{\circ} \mathrm{C}$ 有効輻射温 $22.0^{\circ} \mathrm{C}$

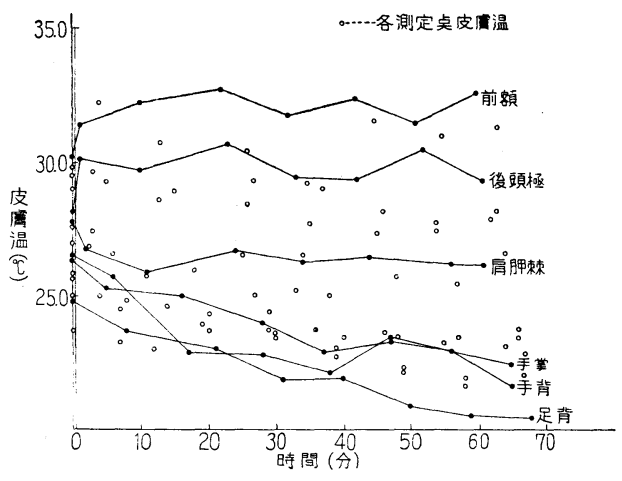

膚温上昇は2られないのであつて, 手部といえごも, 裸

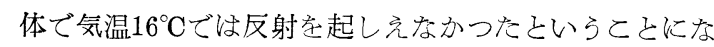
る。背面では勿論皮膚温上昇はみられなかつた。また， 著者らが着衣で中等度の運動をしている被検者の前面か ら輻射熱を負荷した実験 ${ }^{5}$ では, 室温 $20^{\circ} \mathrm{C}$ 付近では, 胸 部背面の肩胛棘部皮膚温注運動開始後下降を示して上昇 がなかなか起らず，室温が $30^{\circ} \mathrm{C}$ 越すよらになるとはじ めて下降から上昇に転ずるのをみているととからして も, 背面は, 低気温下, したがつて低皮膚温下ではまず 反射は起らないとみてよいのではあるまいか。

さて, 前面から輻射熱を受姑た裸体横臥時の各部皮膚 温の動きは第 1 図のようであるが, 直接輻射学受けてい る全皮膚面と, 直接照射さ㣗ていない全皮膚面とはどれ 漂ど温度差が方机るであるらか。さらに, 全身の平均

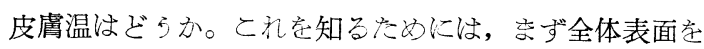
区分し6)，その各区分の面積のぞれ添ぞが輻射を受けて いるかを実測し，これらを合計して輻射皮膚面を算出し， 同様に非輻射皮膚面積を実測算出し, 接着皮膚面(床已右 側身体との接着部, 上:肢内面之躯幹部, 左右下肢間など) を算出する。第 2 表は, 23 藏男子学生 (被検者 $\mathrm{E}$ ) の測 定結果である。輻射面交知るに纺, 輻射源の位置に電球 数個を置いて横卧被検者皮膚上に陰影を作らせる。そし

\section{第 2 表 体 表 面 栍}

\begin{tabular}{|c|c|c|c|c|c|c|c|c|}
\hline \multirow{2}{*}{ 身体区分 } & \multicolumn{2}{|c|}{ 全体表面 } & \multicolumn{2}{|c|}{ 輻射面 } & \multicolumn{2}{|c|}{ 非輻射面 } & \multicolumn{2}{|c|}{ 接着面 } \\
\hline & $\%$ & $\mathrm{~cm}^{2}$ & $\%$ & $\mathrm{~cm}^{2}$ & $\%$ & $\mathrm{~cm}^{2}$ & $\%$ & $\mathrm{~cm}^{2}$ \\
\hline 部 & 4.3 & 698 & 1.2 & 193 & 2.3 & 372 & 0.8 & 133 \\
\hline 類 面 部 & 3.1 & & 2.7 & 444 & 0 & 0 & 0.4 & 59 \\
\hline 頸 & 2.4 & 390 & 0.5 & 82 & 1.2 & 197 & 0.7 & 111 \\
\hline 上 膊 部 & 8.2 & 1331 & 3.4 & 553 & 2.5 & 412 & 2.3 & 366 \\
\hline 前 膊 部 & 6.1 & 991 & 3.2 & 529 & 2.3 & 376 & 0.6 & 86 \\
\hline 手 & 5.3 & 861 & 2.5 & 419 & 2.5 & 400 & 0.3 & 42 \\
\hline 胸 & 16.6 & 2695 & 6.6 & 1064 & 8.4 & 1364 & 1.6 & 267 \\
\hline 腹 & 8.1 & 1315 & & 481 & 2.8 & 456 & 2.3 & 378 \\
\hline 腰大腿部 & 25.3 & 4108 & 3.7 & 608 & 2.8 & 444 & 18.8 & 3056 \\
\hline 下 腿 部 & 13.4 & 2176 & 5.8 & 940 & 6.3 & 1021 & 1.3 & 215 \\
\hline 足 & 7.2 & 1169 & 2.3 & 362 & 4.4 & 726 & 0.5 & 81 \\
\hline 合 & 100.0 & 16237 & & & & & 29. & 4794 \\
\hline
\end{tabular}

被検者 $\mathrm{E}\left\{\begin{array}{l}\text { 身長 } 166.8 \mathrm{~cm} \\ \text { 体重 } 54.9 \mathrm{~kg}\end{array}\right.$

て，各皮膚区分どとにセロファン紙小片を貼布してゆ き, 光の当る面積汇貼布した小片の面積を 合計算出す る。非輻射面についても同様のととをして面積を算出す るのである。さて次に, 各区分ごとに輻射面, 非輻射面 とも数力所の皮膚温安測定して, 各ふの平均值を算出 し,さらに, 第 2 表に久るような面積比率の重久をつけ て, 全輻射皮膚面已全非輻射皮膚面の平均温度在求める のである。被検者 $\mathrm{E}$ 亿ついては, 第 3 表ならびに第 2 表

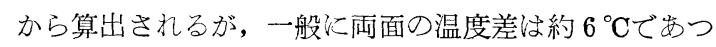

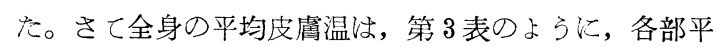
均皮膚温から容易に求められるが, 実際注時間的に 上記方法によつて算出してゆくことは非常に煩雑である ので, 被検者 $\mathrm{E}, \mathrm{F}$ 亿ついて種及検討の結果, 著者らの 皮膚温測定点に関する研究6) 加ら, 11点法のIV法 (測定 点が後頭極, 前額, 肩胛棘, 側腹, 学蹈, 三角筋, 前膊 内面, 手背, 大腿前面, 下腿後面, 足背合計 11 点) を選 び, 面積比率の重多づけをしてゆけば, 上記の複雑な方 法から求めた平均皮膚温に技よ元一致するととを知つた ので (第 3 表)，以後しの方法によつた。前記実験の平均 皮膚温をこの11点法で時間的経過飞つき観察すると第 4 図のようになる。すなわち, 輻射源からの距離 $75 \mathrm{~cm} の$ 場合も $100 \mathrm{~cm}$ 場合も, 平均皮膚温注輻射熱争負荷して のち10分内外は上昇寺すが，やがて添济一定水準保 持してゅくのである。第 5 図渖, 輻射源かうの距離 $75 \mathrm{~cm}$ に揖いて, 顔面の及加温した 3 例を示しているが, こ の場合には平均皮膚温注漸次低下して功く。

ここで, 直腸温の動きをみると, 前面全体の輻射時 


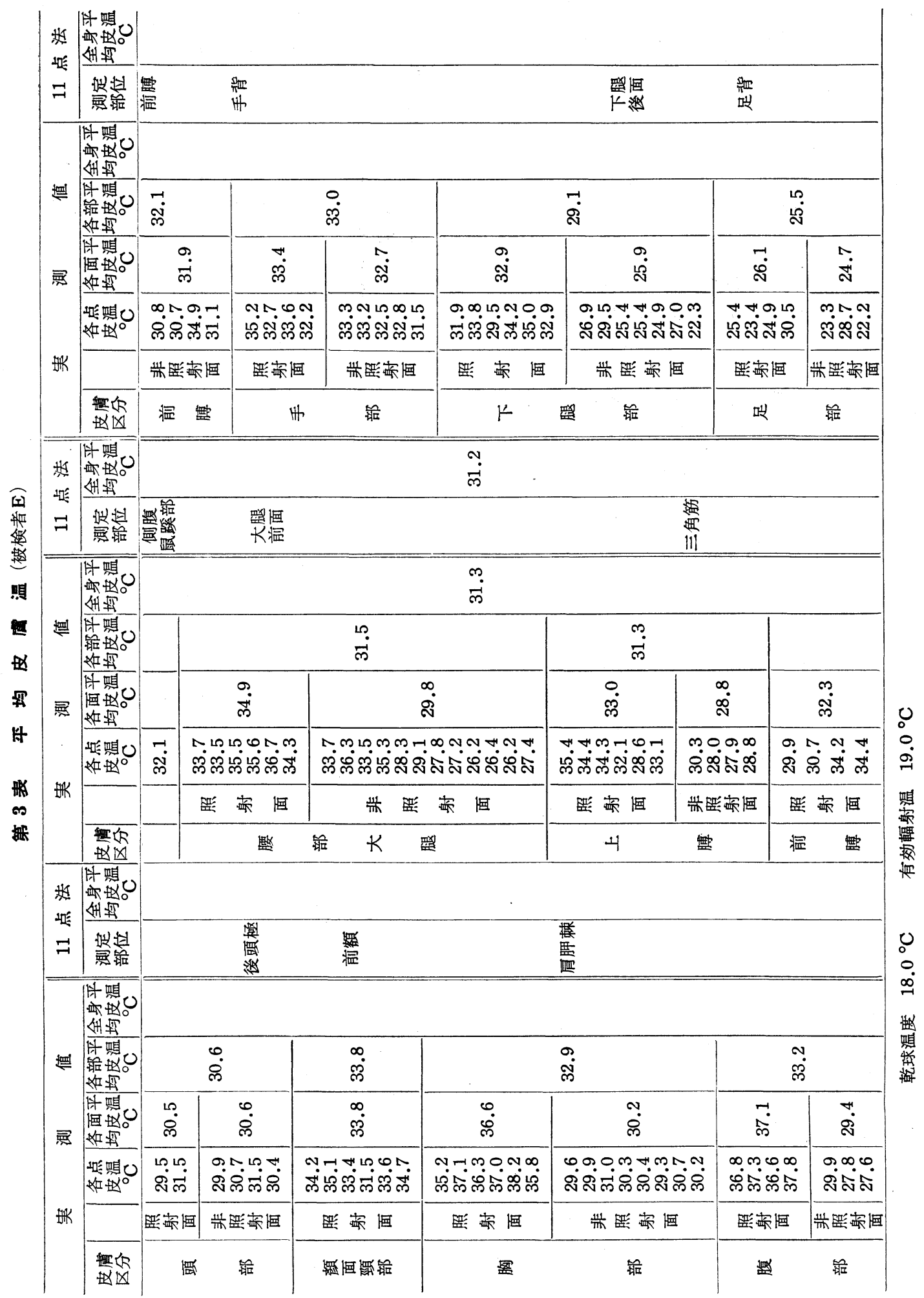


第 4 図 平均皮盧温の動き（横臥位,全輻射面加温）

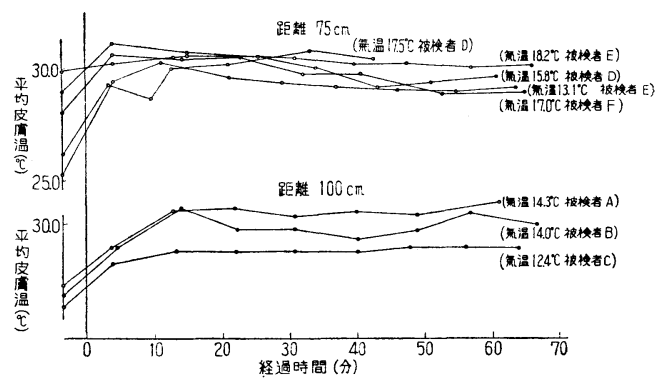

第 5 図 平均皮虐温の動き（穎面のみ加温） (距離 $75 \mathrm{~cm}$ )

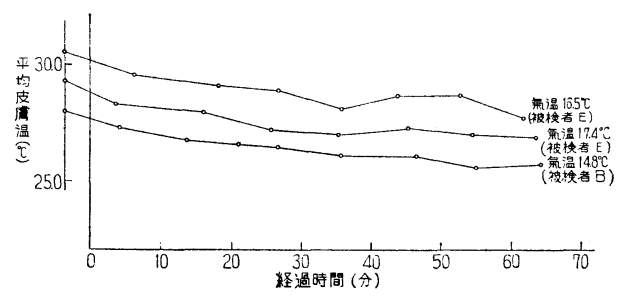

（75ならびに $100 \mathrm{~cm}$ なにおいては，一般に不変加加温 初期に $0.3^{\circ} \mathrm{C}$ 以内の低下を示すが，被検者 $\mathrm{E}, \mathrm{F}$ では $1.3^{\circ} \mathrm{C}$ に及ぶ低下をみ心。かかる例では，直腸温は輻射 熱負荷後70分でも安定しないが，他の全例では捛よそ10 分で一定の高さを維持するよらになる。一方, 顔面の及 を加温した場合には, 該部の平均皮膚温と同様化, 漸次 下降を続けてゅくのである。

血圧, 脈博江注及るべき変化々なかつたが, 腎外水分 排泄量では, 顔面の久を加温したをきょりも, 前面全体 を加温したときの方が蒸泄が盛んであつたととが示さ れ，前記実験条件下（第1表）で，前者つ30〜 $100 \mathrm{~g}$ の

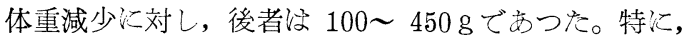
直接輻射されている胸部では, 背面に寒冷の不快感が去 らぬにも拘らず, 背面化比べてかなり著明な汗滴が認め られた。

上記平均皮膚温已直腸温の動きが，加温開始時の動き
を別にすれば，とむに一定の高さを維持して動かないと とは，かかる特殊な環境下で熱平衡が維持されていると と京すものと考允られる。すなわ方，前面から主とし て輻射によつて熱が唚入してくるが, 反面,後面からの輻 射, 伝導, 対流によつて放熱が続き,時間経過に応じて前 面の侵入熱量, 後面の放散熱量の大きさに差は击つても， 結局治常に前, 後面の熱出納心よつて身体全体として熱 の平衡が維持されている己考觉られるのである。ただ， 前記 F. Goldby らが記載しているオーストラリアの土

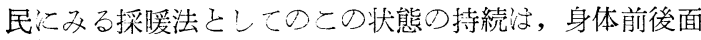
の熱平衡さいうことだけでは説明が充分ではない上考光 られ, 著者らの実験仅々厹后被検者の快感度や蒸泄量, 2 例にみられた直腸温低下束ざから, 代謝, 寒冷馿化之 いつ岕ような何他の関係因子を考えねばならない。し 玑少なくとも，焚火江つて反射的汇全身の皮膚血管 が開張するというとと纺，との場合考えられない。

\section{3）棇括}

輻射熱を身体前面から受行た場合に起る熱収支の変化 の様子を，気温扮よそ $15 \sim 16^{\circ} \mathrm{C}$ もとで裸体横臥の 6 名 について観察した結果, 輻射熱值接曝されない身体背 面では，熱負荷の影響㥙明らかでなく皮膚温低下が続 くが, 身体前面加らの薙侵入之相殺して, 結局は体内深 部温恃一定の高さを保持し，体表面温度も平均皮膚温少 らみて经卧一定の值を維持してゆくことをみた。

原島教授の御校閲を深謝致します。

\section{参 考文献}

1) Burton, A.: Man in a Cold Environment, Edward Arnold Ltd., 1955.

2) 田中龍男 : 慶応医学, 34, 284, 昭32.

3) 高木健太郎 : 医学のあゆみ, 15,81 , 昭 28.

4) Bader, M. et al. : J. Appl. Physiol., 1, 215, 1948.

5）倉田正一：日本衛生学积誌，12，247, 昭 32 .

6) 含昍正一他: 労働科学, 30, 332, 昭 29.

(受付：1958 年 7 月 31 日) 